\title{
Urinary glycosaminoglycan excretion in patients with primary nocturnal enuresis
}

\author{
Yasemin U Budak ${ }^{1 *}$, Kağan Huysal ${ }^{2}$, Atilla Guray ${ }^{3}$
}

\begin{abstract}
Aim: The aim of this study was to determine whether primary nocturnal enuresis (PNE) leads to alterations in glycosaminoglycan (GAG) excretion.

Methods: Twenty subjects (mean age 8.7 years, M/F 15/5) with PNE were included in the study. Twenty-two healthy subjects were selected as a control group (mean age 8.7 years, M/F 14/8). Urinary GAG excretion was measured using a modified dimethylmethylene blue (DMD) assay of 24-hour urine.
\end{abstract}

Results: The mean urinary GAG content was $33.9 \mathrm{mg} / \mathrm{g}$ and $23.8 \mathrm{mg} / \mathrm{g}$ creatinine in patients with PNE and controls, respectively; patients with PNE thus had a higher mean GAG excretion than did age-matched controls ( $p$ $<0.05)$. The association between GAG level and enuresis frequency bordered on significance $(p=0.068)$.

Conclusions: GAG excretion in patients with PNE was significantly higher than in normal children, suggesting that measurement of urinary GAG may be useful in evaluating physiopathological conditions of the bladder wall.

Further studies are needed to confirm this finding.

\section{Background}

Nocturnal enuresis (NE) is defined as repeated, spontaneous voiding of urine during sleep in a child aged 5 years or older [1]. Available evidence indicates that NE is best regarded as a group of conditions with different etiologies rather than a single entity, because only a multifactorial etiology can explain the wide range in outcomes and the fact that different patients respond to different therapies [2]. NE may be classified as primary or secondary [3]. Primary nocturnal enuresis is bedwetting in a child aged 5 years or over who has never been dry for extended periods, whereas secondary nocturnal enuresis is the onset of wetting after a continuous dry period of more than 6-12 months [4]. Primary nocturnal enuresis (PNE) is one of the most frequent complaints in pediatric andurologic practice. PNE is caused by a disparity between bladder capacity and nocturnal urine production, and failure of the child to awaken in response to a full bladder [5]. Despite numerous studies on PNE, the etiology remains elusive.

Recent studies have focused on the importance of glycosaminoglycans (GAGs; linear polysaccharide chains

\footnotetext{
* Correspondence: yaseminbudak2000@yahoo.com
'Department of Clinical Chemistry and Laboratory Medicine, Sevket Yilmaz

* Correspondence: yaseminbudak2000@yahoo.com
'Department of Clinical Chemistry and Laboratory Medicine, Sevket Yilmaz Hospital, Bursa, Turkey
}

(c) 2010 Budak et al; licensee BioMed Central Ltd. This is an Open Access article distributed under the terms of the Creative Commons Attribution License (http://creativecommons.org/licenses/by/2.0), which permits unrestricted use, distribution, and reproduction in any medium, provided the original work is properly cited. acid-amino sugar) that line the transitional epithelium of the human bladder. GAGs play a structural role in the extracellular matrix, regulate ion permeability, and have anti-inflammatory functions on the bladder surface and wall [6-8]. The aim of the present study was to investigate variation in GAG excretion in patients with PNE.

\section{Patients and Methods}

The study included 20 children with PNE (15 boys and 5 girls, mean age 8.7 years, range 6-14 years) and 22 healthy gender- and age-matched controls.

Exclusion criteria were conditions associated with large urine volume, abnormal neurological control, daytime wetting, and previous use of prescription medications for enuresis. Urinary symptoms were evaluated by taking of a history from each affected child and the parents, and by use of a questionnaire and bladder diary. All children underwent urinalysis. No child had any evidence of urinary tract infection (UTI). Exclusion of UTI was based both on urinalysis and absence of symptoms including dysuria, urination frequency or urgency, fever, or costolumbar or suprapubic pain. Pyuria, nitrite in the urine, leukocyte esterase activity (LEA) in the urine, or composed of dimers of a couplet consisting of hexuronic 
Table 1 Bedwetting Frequency

\begin{tabular}{lll}
\hline Frequency & Boys $\mathbf{n}(\%)$ & Girls $\mathbf{n}(\%)$ \\
\hline Every night & $9(45)$ & $1(5)$ \\
$3>$ nights/week & $2(10)$ & $2(10)$ \\
$<3$ nights/wk & $3(15)$ & $3(15)$ \\
\hline
\end{tabular}

positive urine culture $\left(>10^{5} \mathrm{CFU} / \mathrm{mL}\right)$, were all considered evidence of UTI [9].

A dipstick test confirmed no abnormalities in $\mathrm{pH}$ or urine specific gravity, and the absence of protein, glucose, ketones, urobilinogen, bilirubin, or blood. All children had normal renal function, as determined by blood urea and serum creatinine measurements.

Urinary glycosaminoglycan excretion was spectrophotometrically determined in urine samples (at $520 \mathrm{~nm}$ ) after addition of dimethylmethylene blue (SigmaAldrich, St. Louis, MO) using bovine kidney heparan sulfate as a standard (Sigma; catalog no. H 7640) [10]. Under our experimental conditions the intra- and interassay coefficients of variation were $1.5 \%$ and $2.4 \%$ for 10 $\mathrm{mg} / \mathrm{L}$ glycosaminoglycan, respectively. The GAG results were expressed as a GAG/creatinine ( $\mathrm{mg} / \mathrm{g}$, respectively) ratio.
All values are presented as means \pm SDs. Statistical analysis employed SPSS, version 10.0 (SPSS, Inc, Chicago, IL). Statistically significant differences between parameters were established using Student's unpaired $t$ test. Pearson correlations were used to determine the relationship between bedwetting frequency and urinary GAG level. A p value $<0.05$ was considered to indicate a significant difference.

\section{Results}

Of the 20 children currently bedwetting, 10 children had nocturnal enuresis every night, 4 at least three times a week, and 6 once or twice a week (Table 1). The mean urinary GAG content was $33.9 \pm 9.3 \mathrm{mg} / \mathrm{g}$, and $23.8 \pm$ $6.2 \mathrm{mg} / \mathrm{g}$ creatinine, in patients with PNE and controls, respectively; patients with NE thus showed a higher mean GAG excretion than did age-matched controls ( $p$ $<0.05$ ) (Figure 1).

Overall, the correlation between bedwetting frequency and urinary GAG level bordered on significance $(r=$ $0.415, \mathrm{p}=0.068$ ). We consider it likely that future work with larger numbers of patients would show a significant correlation between GAG level and enuresis frequency.

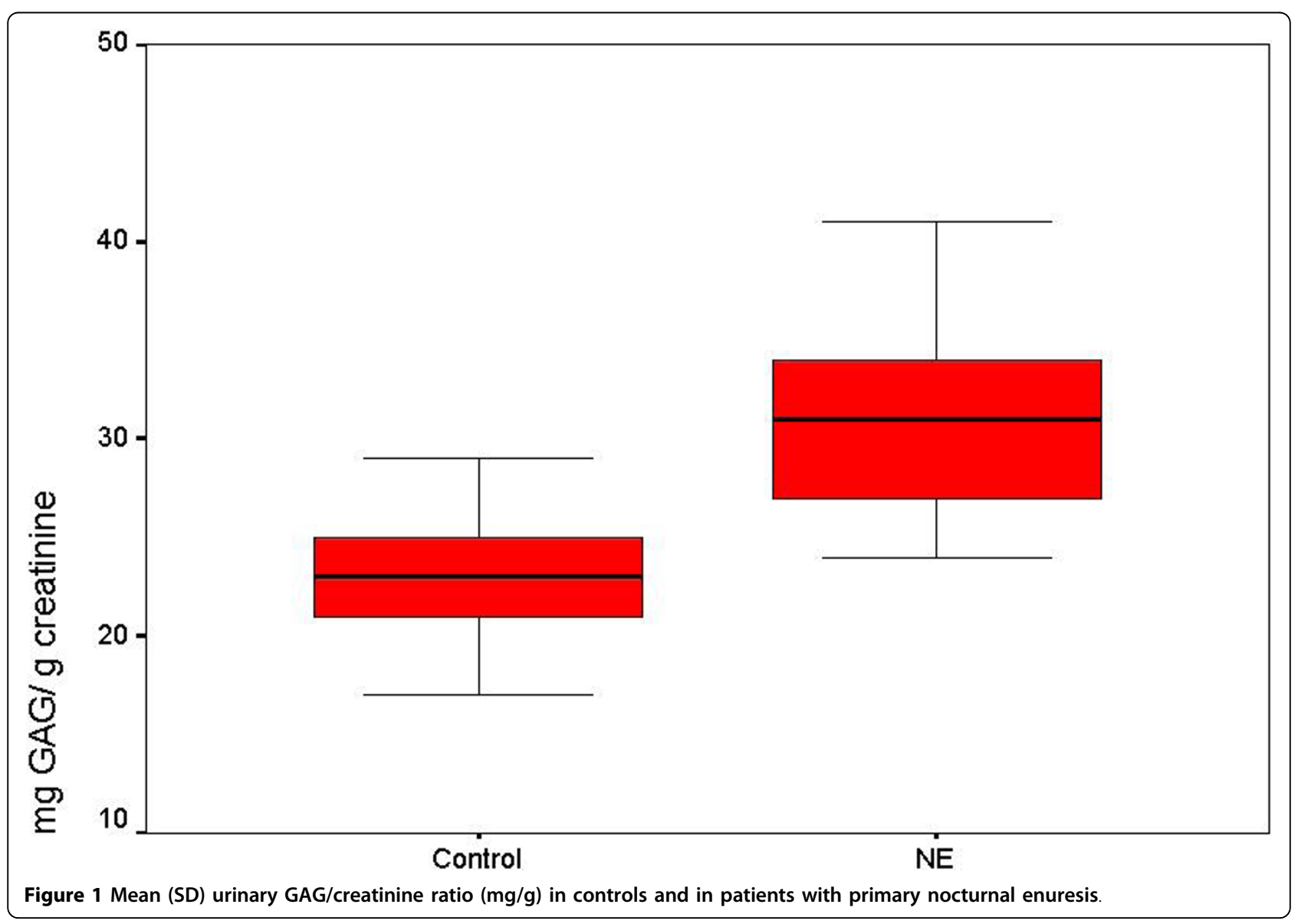




\section{Discussion}

All cells apparently have GAGs on the surface, where the molecules constitute a matrix. Because of the negative charge of sulfate, GAGs repel each other, forming a type of cushion effect when cells interact. GAGs are very important in directing traffic at the surface, and constitute a necessary holding zone for many chemicals that must mutually associate at the cell surface. GAGs prevent small molecules from reaching the underlying tight junctions and cell membranes, and, hence, form a major permeability barrier [11]. Several reports on the functional role of GAGs in the urinary tract have appeared. GAGs are an obligatory constituent of the basal lamina of the urothelium, contributing to maintenance of transmembrane permeability and preventing stone formation $[12,13]$. The presence of GAGs on the bladder wall surface is necessary for inhibition of bacterial adherence and infection, and to avoid tumor cell implantation [14]. GAGs excreted in the urine of healthy subjects or of patients with urological disease ( $e$. $g$., interstitial cystitis or spina bifida) are probably derived from damaged bladder epithelium. Recently, Salvaggio and colleagues found that increased excretion of GAGs in spina bifida patients was an important parameter in evaluation of the physiopathological condition of the bladder wall [15]. The cited authors found that the wall became rich in GAG in patients with neurogenic bladders, leading to wall degeneration. Thus, it was suggested that urinary GAG excretion could be a valuable marker indicating commencement of bladder damage.

Interstitial cystitis is often treated with exogenous GAGs such as heparin, chondroitin sulfate, hyaluronate, or semi-synthetic polysulfate. The mechanism of action is presumed to be coating of the bladder surface to replace chondroitin sulfate and heparin sulfate lost as a result of the disease.

In the present study, GAG excretion was higher in patients with PNE than in healthy controls. Similarly, Ferrara and colleagues found that urinary GAG excretion was significantly elevated in patients with isolated NE compared to controls [16]. They compared GAG excretion in 15 patients with isolated NE, and $12 \mathrm{NE}$ patients who also suffered from diurnal incontinence, with GAG excretion in 27 healthy age-matched controls. The cited authors suggested that measurement of GAG excretion in such patients might be useful for evaluation of the physiopathological condition of the bladder wall, and hence in the monitoring of potential damage to the bladder mucosa.

Caione and associates investigated the effectiveness of a dextranomer/hyaluronic acid copolymer in treatment of urinary incontinence caused by sphincter incompetence in a total of 16 children and adolescents. At 6,12 , and 24 months of follow-up, patients reported improvement in daytime and nighttime dryness, respectively [17].

Increased GAG excretion might result from either immaturity of bladder innervation, or chronic exfoliation of the bladder surface in response to infection. We suggest that quantitative and/or qualitative defects in the GAG layer might lead to reduction in functional bladder capacity.

Although the association between bedwetting frequency and urinary GAG level only bordered on significance, analysis of a larger patient series might permit a stastically significant association between these variables to be demonstrated.

Despite our small sample size, the between-group difference in urinary GAG values attained statistical significance, and we thus suggest that measurement of urinary GAG may be useful in evaluating physiopathological conditions of the bladder wall. Further studies are needed to confirm the validity of this observation.

\section{Acknowledgements}

We did not receive any funding for this study.

\section{Author details}

${ }^{1}$ Department of Clinical Chemistry and Laboratory Medicine, Sevket Yilmaz Hospital, Bursa, Turkey. ${ }^{2}$ Department of Clinical Chemistry and Laboratory Medicine, Yuksek Ihtisas Training Hospital, Bursa, Turkey. ${ }^{3}$ Department of Pediatrics, Sevket Yilmaz Hospital, Bursa, Turkey.

\section{Authors' contributions}

All authors have made substantial contributions to design of the work, in addition to analysis and interpretation of data; and have been involved in drafting the article and revising it critically for important intellectual content; and have given final approval of the version to be published.

\section{Competing interests}

The authors declare that they have no competing interests.

Received: 9 April 2009

Accepted: 3 February 2010 Published: 3 February 2010

\section{References}

1. Ramakrishnan K: Evaluation and treatment of enuresis. Am Fam Physician 2008, 15:489-496.

2. Buttler RJ: Nocturnal enuresis: the child's experience. Oxford: Butterworth Heinemann 1994.

3. Nevéus T, von Gontard A, Hoebeke P, Hjälmås K, Bauer S, Bower W, Jørgensen T, Rittig S, Walle J, Yeung C: The standardization of terminology of lower urinary tract function in children and adolescents: report from the Standardisation Committee of the International Children's Continence Society. J Urol 2006, 176:314-324.

4. World Health Organization: The ICD-10 Classification of Mental and Behavioral Disorders: Diagnostic Criteria for Research. WHO, Geneva 1993.

5. Hjalmas K, Arnold T, Bower W, Caione P, Chiozza L, von Gontard A, HanAN S, Husman D, Kawauchi A, Lackgren G: Nocturnal enuresis: an international evidence based management strategy. J Urol 2004, 171:2545-2561.

6. Parsons CL: A model for the function of glycosaminoglycans in the urinary tract. World J Urol 1994, 12:38-40. 
7. Hurst RE: Structure, function and pathology of proteoglycans and glycosaminoglycans in the urinary tract. World J Urol 1994, 12:3-10.

8. Holm-Bentzen $\mathrm{M}$, Ammitzboll T: Structure and function of glycosaminoglycans in the bladder. Ann Urol 1989, 23:167-168

9. American Academy of Pediatrics Subcommittee on Urinary Tract Infection Practice parameter: the diagnosis, treatment and evaluation of the initial urinary tract infection in febrile infant and young children. Pediatrics 1999, 103:843-852.

10. Jong JGN, Wavera RA, Laarakkers C, Poorthhula BJHM: Dimethylene bluebased spectrophotometry of glycosaminoglycans in untreated urine: a rapid screening procedure for mucopolysaccharidosis. Clin Chem 1989, 35:1472-1477.

11. Lilly JD, Parsons $C L$ : Bladder surface glycosaminoglycans in human epithelialpermeability barrier. Surg Gynecol Obstet 1990, 171:493-496.

12. Hook M, Kjellen L, Johansson S: Cell-surface glycosaminoglycans. Annu Rev Biochem 1984, 53:847-869.

13. Hesse A, Wuzel $H$, Vahlensieck W: The excretion of glycosaminoglycans in the urine of calcium-oxalate stone patients and healthy persons. Urol Int 1986, 41:81-87.

14. Huerst RE, Rhodes SW, Adamson PB, Parsons CL, Roy JB: Functional and structural characteristics of the glycosaminoglycans of the bladder luminal surface. J Urol 1987, 138:433-437.

15. Salvaggio E, Antuzzi D, Ferrara P, Scanu M, Pulitaro S, Venuti L, Targuini E, De Miclabe T, Ricei R: Glycosaminoglycans: urinary excretion in children with myelomeningocel. Urol Int 2001, 66:156-159.

16. Ferrara P, Rigante D, Lambert-Gardini S, Salvaggio E, Ricei R, Chiozza ML, Antuzzi D: Urinary excretion of glycosaminoglycans in patients with isolated nocturnal enuresis or combined with diurnal incontinence. BJU Int 2000, 86:824-825.

17. Caione $P$, Capozza N: Endoscopic treatment of urinary incontinence in pediatric patients: 2-year experience with dextranomer/hyaluronic acid copolymer. J Urol 2002, 168:1868-1871.

doi:10.1186/1824-7288-36-13

Cite this article as: Budak et al:: Urinary glycosaminoglycan excretion in patients with primary nocturnal enuresis. Italian Journal of Pediatrics 2010 36:13.

\section{Submit your next manuscript to BioMed Central and take full advantage of:}

- Convenient online submission

- Thorough peer review

- No space constraints or color figure charges

- Immediate publication on acceptance

- Inclusion in PubMed, CAS, Scopus and Google Scholar

- Research which is freely available for redistribution 